\title{
Vildagliptin: a new oral treatment for type 2 diabetes mellitus
}

\author{
Chantal Mathieu \\ Evy Degrande
}

Department of Endocrinology, Katholieke Universiteit Leuven, Leuven, Belgium
Correspondence: Chantal Mathieu Endocrinology, UZ Gasthuisberg, Herestraat 49, 3000 Leuven, Belgium Tel +32 I 6346994

Fax +32 I6 345934

Email chantal.mathieu@med.kuleuven.be

\begin{abstract}
Vildagliptin is a new oral antidiabetic agent that enhances pancreatic islet cell responsiveness to glucose. An extensive clinical program involving approximately 22,000 patients and 7000 patient-years of exposure to vildagliptin has shown that the agent is well tolerated and efficacious in improving glycemic control in patients with type 2 diabetes mellitus (T2DM). Monotherapy trials have shown that significant HbA1c lowering is accompanied by body weight-neutral and lipid-neutral effects, low risk of edema, and low risk of hypoglycemia. These characteristics make vildagliptin a favorable partner for combination therapy. Studies of vildagliptin as an add-on to metformin have shown significant improvements in glycemic control (comparable to that of thiazolidinedione add-on), with the combination being well tolerated and associated with low risks for hypoglycemia and adverse effects on weight or lipid levels. Good tolerability and clinically relevant improvements in glycemic control have also been observed with vildagliptin as an add-on treatment to sulfonylurea, thiazolidinedione, or insulin treatment or in initial combination treatment with pioglitazone. Improved $\beta$-cell function and glycemic control have been shown with vildagliptin in subjects with impaired glucose tolerance and in T2DM patients with mild hyperglycemia, with some evidence in the latter suggesting the potential for modifying disease course.
\end{abstract}

Keywords: diabetes, vildagliptin, incretin, metformin, add-on treatment, hypoglycemia

Type 2 diabetes mellitus (T2DM) is a dual disease, characterized by islet (beta- and alpha-) cell dysfunction in the setting of insulin resistance. Moreover, ample clinical evidence, such as data from the landmark UK Prospective Diabetes Study (UKPDS), indicates that loss of beta-cell function is progressive. This progressive decline leads to the clinical impression of failure of therapy in T2DM patients and is the main reason why so many patients with T2DM are not within target ranges of glycemic control. Moreover, the clear alpha-cell dysfunction that is also present in T2DM has been disregarded in previous years, mainly because therapeutic interventions were lacking. The need to address this underlying islet cell deficit led to a search for therapeutic alternatives and has led to the rediscovery of the incretin hormones and their role in glucose homeostasis. Improved understanding of their potential has led in turn to the development of incretin analogs and incretin enhancers for treatment of T2DM (Deacon 2004; Vilsbøll and Holst 2004; Drucker 2006; Deacon et al 2008).

The present review will discuss the data available on the incretin enhancer vildagliptin, a potent and selective inhibitor of dipeptidyl peptidase-4 (DPP-4), the enzyme responsible for the rapid degradation of the incretin hormones glucagonlike peptide-1 (GLP-1) and glucose-dependent insulinotropic peptide (GIP). This activity increases levels of active incretins and enhances pancreatic islet $\alpha$ - and $\beta$-cell responsiveness to glucose, thus improving insulin secretion and reducing inappropriate glucagon production, improving insulin sensitivity, improving postprandial lipid and 
lipoprotein metabolism, and reducing fasting and prandial glucose and HbA1c (Ahrén et al 2004; Ahrén et al 2005; Mari et al 2005; Burkey et al 2006; D’Alessio et al 2006; Matikainen et al 2006; Balas et al 2007; He et al 2007a; Vella et al 2007; Azuma et al 2008; Deacon et al 2008). Finally, we will discuss the best position for this drug in our therapeutic arsenal to address glycemic control in T2DM patients.

\section{Vildagliptin: clinical program}

Most data available on vildagliptin until now have come from company-sponsored studies designed for registration purposes. The drug has been evaluated in an extensive, ongoing clinical program, involving approximately 22,000 treated patients overall and 14,200 vildagliptin-treated patients representing approximately 7000 subject-years of vildagliptin exposure as of April 2008 (data on file, Novartis). It is currently approved for use in treatment of T2DM in the European Union, Latin America (Brazil, Mexico), and Asia (Korea, Singapore, Philippines). As reviewed herein, clinical trials have shown that vildagliptin improves glycemic control in patients with T2DM as monotherapy (Pi-Sunyer et al 2007; Dejager et al 2007; Rosenstock et al 2007a; Schweizer et al 2007; Pan et al 2008) and as add-on or initial combination therapy with other oral antidiabetic agents and insulin (Bosi et al 2007a; Fonseca et al 2007; Garber et al 2007; Rosenstock et al 2007b; Bolli et al 2008; Garber et al 2008), as well as in patients with impaired glucose tolerance (IGT) (Rosenstock et al 2008; Utzschneider et al 2008). Recent evidence from T2DM patients with mild hyperglycemia indicates that vildagliptin attenuates deterioration of $\beta$-cell function over long-term treatment (Mari 2008; Scherbaum 2008a; Scherbaum 2008b). Vildagliptin treatment is characterized by weight-neutral and lipid-neutral effects, very low risk of edema, and very low risk of hypoglycemia.

T2DM is characterized by continual loss of glycemic control despite treatment, with few patients achieving and maintaining treatment goals and combination treatment typically becoming unavoidable (UKPDS 1998; Saydah 2004; Kahn 2006). Current guidelines encourage a prompt move to combination treatment when initial metformin treatment fails to achieve glycemic goals (Nathan et al 2006). The primary utility of vildagliptin is likely to be as add-on treatment or in initial combination with metformin. These agents have complementary effects in improving glycemic control, potential mechanistic synergy, and a favorable interaction of tolerability profiles, including absence of risk for weight gain, edema, and hypoglycemia. In the European Union, vildagliptin $\left(\right.$ Galvus $^{\circledR}$ ) is approved for use at $50 \mathrm{mg}$ bid in combination with metformin or a thiazolidinedione and at $50 \mathrm{mg}$ qd in combination with a sulfonylurea (SU). A fixed-dose vildagliptin/metformin combination is approved for use in $50 \mathrm{mg} / 850 \mathrm{mg}$ and $50 \mathrm{mg} / 1000 \mathrm{mg}$ formulations.

\section{Pharmacologic overview}

Vildagliptin is rapidly absorbed after oral administration, with approximately dose-proportional pharmacokinetics (He 2007b; He 2007c). No dosage adjustment is necessary based on age, gender, body mass index (BMI), food intake, presence of hepatic impairment, or concomitant use of commonly used drugs (He et al 2008a; He et al 2007d; He et al 2007e; He et al 2007f; Sunkara 2007; He et al 2008b). Bioequivalence of the fixed-dose combination of vildagliptin and metformin with the individual components has been shown; the effect of food in decreasing metformin exposure was smaller with the metformin component in the fixed-dose combination than has been reported with metformin alone, and the fixed-dose combination can thus be administered in the same manner as metformin alone (He et al 2008c; He et al 2008d).

\section{Vildagliptin monotherapy trials}

Vildagliptin has been evaluated as monotherapy in treatmentnaïve T2DM patients in randomized, double-blind doseranging and comparative trials, including comparisons with metformin, rosiglitazone, and acarbose; in subjects with impaired glucose tolerance; and in T2DM patients with mild hyperglycemia.

\section{Dose-ranging studies}

In one dose-ranging study, 354 patients (HbA1c 7.5\%-10.0\%, baseline average $8.4 \%$ ) were randomized to vildagliptin $50 \mathrm{mg}$ qd $(\mathrm{n}=88), 50 \mathrm{mg}$ bid $(\mathrm{n}=83)$, or $100 \mathrm{mg} \mathrm{qd}$ $(\mathrm{n}=91)$ or to placebo $(\mathrm{n}=92)$ for 24 weeks (Pi-Sunyer 2007). Placebo-subtracted mean changes from baseline in HbAlc were $0.5 \%, 0.7 \%$, and $0.9 \%$, respectively, in the three vildagliptin dose groups (all $\mathrm{p} \leq 0.01$ vs placebo). Placebo-subtracted reductions from baseline fasting plasma glucose (FPG; baseline average $10.5 \mathrm{mmol} / \mathrm{L}$ ) were 0.6 , 1.3 , and $1.3 \mathrm{mmol} / \mathrm{L}$, respectively $(\mathrm{p}<0.001$ for latter two dose groups). Adverse events occurred with similar frequency with vildagliptin $(55.8 \%-59.3 \%)$ and placebo $(57.6 \%)$. There was no significant change in weight, and no episodes of hypoglycemia occurred with vildagliptin treatment. In a second dose-ranging study, 632 patients (HbA1c 7.5\%-11.0\%, baseline 8.4\%) were randomized to vildagliptin $50 \mathrm{mg}$ qd $(\mathrm{n}=163), 50 \mathrm{mg}$ bid $(\mathrm{n}=152)$, or 
$100 \mathrm{mg}$ qd $(\mathrm{n}=157)$ or to placebo $(\mathrm{n}=160)$ for 24 weeks (Dejager et al 2007). Changes in HbA1c from baseline were $-0.3 \%$ with placebo vs $-0.8 \%,-0.8 \%$, and $-0.9 \%$ with vildagliptin $50 \mathrm{mg}$ qd, $50 \mathrm{mg}$ bid, and $100 \mathrm{mg}$ qd, respectively ( $p<0.01$ for all). Body weight decreased by $0.3-1.8 \mathrm{~kg}$ across all groups. Mild hypoglycemia occurred in 2 patients $(1.2 \%)$ receiving vildagliptin $50 \mathrm{mg}$ qd, in 1 patient $(0.6 \%)$ receiving $100 \mathrm{mg} \mathrm{qd}$, and in none of the patients receiving $50 \mathrm{mg}$ bid or placebo.

\section{Comparison with metformin}

In a noninferiority trial, 780 patients (HbA1c 7.5\%-11.0\%, average $8.7 \%$ ) were randomized to vildagliptin $50 \mathrm{mg}$ bid $(\mathrm{n}=526)$ or metformin $1000 \mathrm{mg}$ bid $(\mathrm{n}=254)$ for 52 weeks (Schweizer et al 2007). Mean changes in HbAlc were $-1.0 \%$ with vildagliptin $(\mathrm{p}<0.001)$ and $-1.4 \%$ with metformin $(\mathrm{p}<0.001)$, with the criterion for noninferiority not being met by vildagliptin. In patients with baseline $\mathrm{HbA} 1 \mathrm{c} \leq 8 \%$ (mean $\sim 7.6 \%$ ), mean changes at 24 weeks were similar with vildagliptin $(-0.6 \%, \mathrm{n}=180)$ and metformin $(-0.7 \%, \mathrm{n}=79)$. In an extension study, where patients were on treatment for 2 years, $\mathrm{HbA} 1 \mathrm{c}$ reductions were sustained at $-1.0 \%$ with vildagliptin $(\mathrm{n}=243)$ and $-1.5 \%$ with metformin $(\mathrm{n}=136)$ (data on file, Novartis).

Over 52 weeks, there was no significant change in body weight with vildagliptin and a $1.9-\mathrm{kg}$ weight loss with metformin $(\mathrm{p}<0.001)$, and hypoglycemia occurred in $0.6 \%$ of vildagliptin patients and $0.4 \%$ of metformin patients. Adverse events were similar in frequency with vildagliptin (70.1\%) and metformin (75.4\%), but vildagliptin was associated with significantly fewer gastrointestinal (GI) adverse events $(22 \%$ vs $44 \%, \mathrm{p}<0.001)$. Among patients with diastolic blood pressure (DBP) $\geq 90 \mathrm{mmHg}$ (vildagliptin, $\mathrm{n}=89$; metformin, $\mathrm{n}=53$; baseline $94 \mathrm{mmHg}$ ) or systolic blood pressure (SBP) $\geq 140 \mathrm{mmHg}$ (vildagliptin, $\mathrm{n}=150$; metformin, $\mathrm{n}=84$; baseline $149-150 \mathrm{mmHg}$ ), vildagliptin was associated with a significantly greater decrease in DBP (7.5 vs $4.2 \mathrm{mmHg}, \mathrm{p}<0.05)$ and SBP (9.1 vs 5.3, p < 0.05) (Bosi 2 et al 007b).

\section{Comparison with rosiglitazone}

In a noninferiority trial, 786 patients (HbA1c $7.5 \%-11.0 \%$, mean $\sim 8.7 \%$ ) were randomized to vildagliptin $50 \mathrm{mg}$ bid $(n=519)$ or rosiglitazone $8 \mathrm{mg}$ qd $(n=267)$ for 24 weeks (Rosenstock et al 2007a). Mean changes in HbA1c from baseline were $-1.1 \%$ with vildagliptin vs $-1.3 \%$ with rosiglitazone, with vildagliptin meeting the noninferiority criterion. Among patients with baseline HbAlc $>9.0 \%$ (vildagliptin, $\mathrm{n}=166$; rosiglitazone, $\mathrm{n}=88$; mean $\sim 10.0 \%$ ), mean reductions were $1.8 \%$ vs $1.9 \%$. Overall, vildagliptin was associated with a $0.3-\mathrm{kg}$ reduction in body weight, vs a $1.6-\mathrm{kg}$ increase with rosiglitazone $(\mathrm{p}<0.001)$; among patients with baseline BMI $\geq 35 \mathrm{~kg} / \mathrm{m}^{2}$ (vildagliptin, $\mathrm{n}=132$; rosiglitazone, $\mathrm{n}=76$; body weight $111-112 \mathrm{~kg}$ ), vildagliptin patients lost $1.1 \mathrm{~kg}$, compared with a gain of $1.7 \mathrm{~kg}$ with rosiglitazone $(\mathrm{p}<0.001)$. The frequency of adverse events was similar in the two groups (61.4\% and 64.0\%), and one case of mild hypoglycemia occurred in each group. Peripheral edema was reported in $2.1 \%$ of vildagliptin patients and $4.1 \%$ of rosiglitazone patients. Changes in atherogenic lipids consisted of small decreases with vildagliptin and moderate increases with rosiglitazone in triglycerides $(p=0.01)$, total cholesterol ( $p \leq 0.003)$, and LDL cholesterol ( $p \leq 0.003)$, with a greater increase in HDL cholesterol occurring with rosiglitazone $(\mathrm{p} \leq 0.003)$.

\section{Comparison with acarbose}

In a noninferiority trial, 661 patients (HbA1c 7.5\%-11.0\%, mean $\sim 8.6 \%$ ) were randomized to vildagliptin $50 \mathrm{mg}$ bid $(n=441)$ or acarbose up to $100 \mathrm{mg}$ tid $(n=220)$ for 24 weeks (Pan et al 2008). Mean changes in HbA1c were $1.4 \%$ with vildagliptin and $1.3 \%$ with acarbose, with vildagliptin meeting the noninferiority criterion. Among patients with baseline $\mathrm{HbA} 1 \mathrm{c}>9.0 \%$ (vildagliptin, $\mathrm{n}=146$; acarbose, $\mathrm{n}=63$; mean $\sim 9.8 \%$ ), reductions were $2.0 \%$ and $2.1 \%$, respectively. Body weight decreased by $0.4 \mathrm{~kg}$ with vildagliptin and by $1.7 \mathrm{~kg}$ with acarbose $(\mathrm{p}<0.001)$. Adverse events occurred in $35 \%$ of vildagliptin patients and in $51 \%$ of acarbose patients, with a significant reduction in GI adverse events with vildagliptin $(12.3 \%$ vs $25.5 \%$, p $<0.001)$. No hypoglycemia occurred in either group.

\section{Impaired glucose tolerance}

In a randomized, double-blind trial, 179 subjects with IGT (2-h glucose $9.1 \mathrm{mmol} / \mathrm{L}, \mathrm{HbA} 1 \mathrm{c} 5.9 \%$ ) were randomized to vildagliptin $50 \mathrm{mg}$ qd $(\mathrm{n}=90)$ or placebo $(\mathrm{n}=89)$ for 12 weeks (Rosenstock et al 2008). Compared with placebo, vildagliptin significantly increased levels of GLP-1 and GIP and reduced glucagon levels. Postprandial insulin levels were unaffected, and vildagliptin treatment was associated with a significant reduction in prandial glucose excursion (incremental area under the curve [AUC] $-1.0 \mathrm{mmol} / \mathrm{L} / \mathrm{h}$, $\mathrm{p}<0.001$ ), representing a $32 \%$ reduction vs placebo. $\beta$-cell function, assessed by insulin secretory rate (ISR) relative to glucose measured as ISR $\mathrm{AUC}_{0-2 \mathrm{~h}} /$ glucose $\mathrm{AUC}_{0-2 \mathrm{~h}}$, was significantly increased $\left(+6.4 \mathrm{pmol} / \mathrm{min} / \mathrm{m}^{2} / \mathrm{mM}, \mathrm{p}=0.002\right)$ 
with vildagliptin. Adverse event profiles were similar for vildagliptin and placebo. No cases of hypoglycemia were reported. Change in body weight was $-0.6 \mathrm{~kg}$ with vildagliptin and $-0.1 \mathrm{~kg}$ with placebo.

\section{Mild hyperglycemia}

A total of 306 patients with T2DM and mild hyperglycemia (HbAlc 6.2\%-7.5\%) were randomized to vildagliptin $50 \mathrm{mg}$ qd $(\mathrm{n}=156)$ or placebo $(\mathrm{n}=150)$ for 52 weeks followed by a 4-week washout period (Mari et al 2008; Scherbaum et al 2008a). At baseline, HbA1c and FPG were $6.7 \%$ and $7.1 \mathrm{mmol} / \mathrm{L}$, respectively, in the vildagliptin group and $6.8 \%$ and $7.2 \mathrm{mmol} / \mathrm{L}$, respectively, in the placebo group. At 52 weeks, changes in HbA1c were $-0.2 \%$ with vildagliptin vs $+0.1 \%$ with placebo (between-group difference $\mathrm{p}<0.001)$; FPG did not change significantly with vildagliptin $(+0.2 \mathrm{mmol} / \mathrm{L})$ and increased with placebo $(+0.5 \mathrm{mmol} / \mathrm{L}, \mathrm{p}<0.001$; between-group difference $\mathrm{p}=0.032$ ). Compared with patients on placebo, vildagliptin patients had a significant reduction in 2-hour postprandial glucose $(-0.9 \mathrm{mmol} / \mathrm{L}, \mathrm{p}=0.012)$ and significantly improved $\beta$-cell function assessed as ISR $\mathrm{AUC}_{0-2 \mathrm{~h}} /$ glucose $\mathrm{AUC}_{0-2 \mathrm{~h}}\left(+5.0 \mathrm{pmol} / \mathrm{min} / \mathrm{m}^{2} / \mathrm{mM}, \mathrm{p}<0.001\right)$ (Scherbaum et al 2008a).

Additional characterization of the effect of vildagliptin on model-assessed $\beta$-cell function (Mari 2008) showed that the $0.3 \%$ reduction in $\mathrm{HbA} 1 \mathrm{c}$ and significantly reduced glucose $\mathrm{AUC}_{0-2 \mathrm{~h}}(-1.7 \mathrm{mM} / \mathrm{h}, \mathrm{p}=0.002)$ were accompanied by significantly increased fasting insulin secretory tone $(+34.1 \mathrm{pmol} /$ $\left.\mathrm{min} / \mathrm{m}^{2}, \mathrm{p}<0.001\right)$, glucose sensitivity $\left(+20.7 \mathrm{pmol} / \mathrm{min} / \mathrm{m}^{2} /\right.$ $\mathrm{mM}, \mathrm{p}<0.001)$, and rate sensitivity $\left(163.6 \mathrm{pmol} / \mathrm{m}^{2} / \mathrm{mM}\right.$, $\mathrm{p}=0.015$ ), with total insulin secretion (ISR $\mathrm{AUC}_{0-2 \mathrm{~h}}$ ) and a potentiation factor (expressing relative potentiation of insulin secretory response to glucose) during meals remaining unchanged. Body weight decreased by $0.5 \mathrm{~kg}$ with vildagliptin and by $0.2 \mathrm{~kg}$ with placebo. Adverse events were similar in the two groups; hypoglycemia occurred in none of the vildagliptin patients and in one placebo patient.

After this study of 52 weeks, a washout period of 4 weeks was built in, followed by continuation of therapy in a subgroup of patients $(n=131)$. None of the effects of vildagliptin treatment at 52 weeks were present after the 4-week washout period, suggesting absence of a potential disease-modifying effect over 1 year of treatment. The potential for such an effect is suggested by preclinical studies showing that GLP-1, incretin mimetics, and DPP-4 inhibitors inhibit apoptosis, augment $\beta$-cell function, and increase $\beta$-cell mass in rodent models with a high rate of $\beta$-cell turnover (Baggio and
Drucker 2006). However, results of the 52-week extension after the 4-week washout following the core 52-week study (total 104 treatment weeks and 4 weeks washout period) suggest that vildagliptin treatment may attenuate deterioration of $\beta$-cell function over 2 years of treatment in mild hyperglycemia (Scherbaum et al 2008b). Among the 131 patients in the extension study (vildagliptin, $n=68$; placebo, $n=63$ ), vildagliptin patients had a significant reduction vs placebo in HbA1c after the second 52-week treatment period $(-0.5 \%$, $\mathrm{p}=0.008)$. Placebo-adjusted changes from core study baseline values in FPG, glucose $\mathrm{AUC}_{0-2 \mathrm{~h}}$, and ISR AUC $\mathrm{AU}_{2 \mathrm{~h}}$ ' glucose $\mathrm{AUC}_{0-2 \mathrm{~h}}$ tended to be greater after 2 years than after 1 year of vildagliptin treatment. After the second washout period (week 112), the placebo-adjusted change from week 0 to week 112 in ISR AUC $_{0-2 \mathrm{~h}} /$ glucose $\mathrm{AUC}_{0-2 \mathrm{~h}}$ was $3.2 \mathrm{pmol} /$ $\mathrm{min} / \mathrm{m}^{2} / \mathrm{mM}(\mathrm{p}=0.058)$ and the placebo-adjusted change in $\mathrm{HbA1c}$ was $-0.3 \%(\mathrm{p}=0.051)$, indicating an attenuated rate of loss of glycemic control in the absence of active treatment. Adverse events were similar in the two groups; two placebo patients and no vildagliptin patients had hypoglycemia. Body weight did not change significantly in placebo patients $(-0.3 \mathrm{~kg})$ and decreased significantly in vildagliptin patients $(-1.1 \mathrm{~kg}, \mathrm{p}=0.026)$ compared with core study baseline.

\section{Summary of pooled monotherapy results}

Pooled 24-week data from monotherapy arms (data on file, Novartis) show that vildagliptin is effective across the range of levels of hyperglycemia and baseline BMI values and in older and younger patients. For all patients receiving $50 \mathrm{mg}$ bid $(\mathrm{n}=1569)$, change in $\mathrm{HbA} 1 \mathrm{c}$ from baseline was $-1.0 \%$, including changes of $-0.6 \%$ in those with baseline HbA1c $\leq 8.0 \%(n=543),-0.9 \%$ for baseline HbA1c $>8.0-9.0 \%(n=490),-1.6 \%$ for baseline HbA1c $>9.0 \%-10.0 \%(n=362)$, and $-1.9 \%$ for baseline HbA1c $>10.0 \%(n=174)(p<0.001$ for all compared with baseline). Reductions from baseline HbA1c (8.6\%-8.7\%) according to BMI with vildagliptin $50 \mathrm{mg}$ bid were $1.1 \%$ and $0.9 \%$ for $<30 \mathrm{~kg} / \mathrm{m}^{2}(\mathrm{n}=819)$ and $>30 \mathrm{~kg} / \mathrm{m}^{2}(\mathrm{n}=748)$, respectively, and $1.1 \%$ and $1.0 \%$ for $<35 \mathrm{~kg} / \mathrm{m}^{2}(\mathrm{n}=1202)$ and $>35 \mathrm{~kg} / \mathrm{m}^{2}(\mathrm{n}=365)$, respectively $(\mathrm{p}<0.001$ for all vs baseline). Reductions with $50 \mathrm{mg}$ bid were $1.1 \%$ in both patients aged $<65$ years $(n=1326$, baseline $8.7 \%)$ and those aged $>65$ years $(n=243$, baseline $8.4 \%)$.

Changes in fasting lipids with vildagliptin treatment were minor, consisting of reductions of $0.6 \%, 2.7 \%$, and $2.0 \%$ in triglycerides, total cholesterol, and LDL cholesterol, respectively, and an increase of $3.9 \%$ in HDL cholesterol at the $50 \mathrm{mg}$ bid dose. Rates of peripheral edema were similar to that seen 
with placebo, consisting of $0.9 \%$ with vildagliptin $50 \mathrm{mg}$ qd $(\mathrm{n}=655), 1.3 \%$ with vildagliptin $50 \mathrm{mg}$ bid $(\mathrm{n}=2251)$, $2.0 \%$ with metformin up to $2000 \mathrm{mg} / \mathrm{d}(\mathrm{n}=252), 4.1 \%$ with rosiglitazone $8 \mathrm{mg} / \mathrm{d}(\mathrm{n}=267), 7.9 \%$ with pioglitazone $30 \mathrm{mg} / \mathrm{d}(\mathrm{n}=216$, in a monotherapy arm in a combination study discussed below), and $1.2 \%$ with placebo $(n=586)$. There was a low risk of hypoglycemia, and rates of other clinical adverse events were comparable to those seen with placebo (Table 1).

\section{Combination therapy}

Vildagliptin has been assessed in randomized, double-blind trials as add-on therapy to metformin, SU, thiazolidinedione, and insulin treatment and in initial combination with pioglitazone.

\section{Vildagliptin as add-on to metformin}

\section{Add-on to metformin vs placebo}

A total of 544 patients with inadequate glycemic control (HbA1c 7.5\%-11.0\%; mean $8.3 \%-8.4 \%$ ) on a metformin regimen of $\geq 1500 \mathrm{mg} / \mathrm{d}$ were randomized to vildagliptin $50 \mathrm{mg}$ qd $(\mathrm{n}=177)$ or $50 \mathrm{mg}$ bid $(\mathrm{n}=185)$ or placebo $(n=182)$ while continuing on metformin for 24 weeks; metformin in all patients was titrated up to $\geq 2000 \mathrm{mg} / \mathrm{d}$ by study baseline, and the mean study dose was $2100 \mathrm{mg} / \mathrm{d}$ (Bosi et al 2007a). HbA1c was reduced by a mean of $0.7 \%$ with the addition of vildagliptin $50 \mathrm{mg}$ qd and by $1.1 \%$ with vildagliptin $50 \mathrm{mg}$ bid compared with metformin/placebo (both $\mathrm{p} \leq 0.001$ ) (Figure 1). FPG (baseline 9.7-10.1 mmol/L) was reduced by $0.8 \mathrm{mmol} / \mathrm{L}(\mathrm{p}=0.003)$ and $1.7 \mathrm{mmol} / \mathrm{L}$ ( $\mathrm{p}<0.001$ ), respectively, with vildagliptin $50 \mathrm{mg} \mathrm{qd}$ and bid. In predefined analyses, the addition of vildagliptin $50 \mathrm{mg}$ bid produced changes in HbA1c vs metformin/placebo of $-1.3 \% \mathrm{vs}-0.2 \%$ in patients aged $\geq 65$ years (vildagliptin, $\mathrm{n}=20$; metformin/placebo, $\mathrm{n}=22$; baseline $\sim 8.3 \%$ ), $-0.8 \%$ vs $+0.2 \%$ in those with baseline BMI $\geq 30 \mathrm{~kg} / \mathrm{m}^{2}$ (vildagliptin, $n=103$; metformin/placebo, $n=86$; baseline $\sim 8.3 \%$ ), and $-1.3 \%$ vs $0.0 \%$ in those with baseline $\mathrm{HbAlc}>9.0 \%$ (vildagliptin, $\mathrm{n}=29$; metformin/placebo, $\mathrm{n}=29$ ) (data on file, Novartis). The HbA1c target of $<7.0 \%$ was reached in $54 \%$ of vildagliptin $50 \mathrm{mg}$ bid patients, $50 \%$ of vildagliptin $50 \mathrm{mg}$ qd patients, and $14 \%$ of metformin/placebo patients starting treatment with $\mathrm{HbA} 1 \mathrm{c} \geq 8.0 \%$ and in $31 \%, 22 \%$, and $13 \%$, respectively, of those starting at $\mathrm{HbA} 1 \mathrm{c}>8.0 \%-8.5 \%$ (Bosi et al 2007a). Improved $\beta$-cell function with the addition of vildagliptin was shown by significant increases in adjusted mean ISR $\mathrm{AUC}_{0-2 \mathrm{~h}} /$ glucose $\mathrm{AUC}_{0-2 \mathrm{~h}}$ with vildagliptin qd $\left(\mathrm{n}=53 ;+6.9 \mathrm{pmol} / \mathrm{min} / \mathrm{m}^{2} / \mathrm{mM}\right)$ and

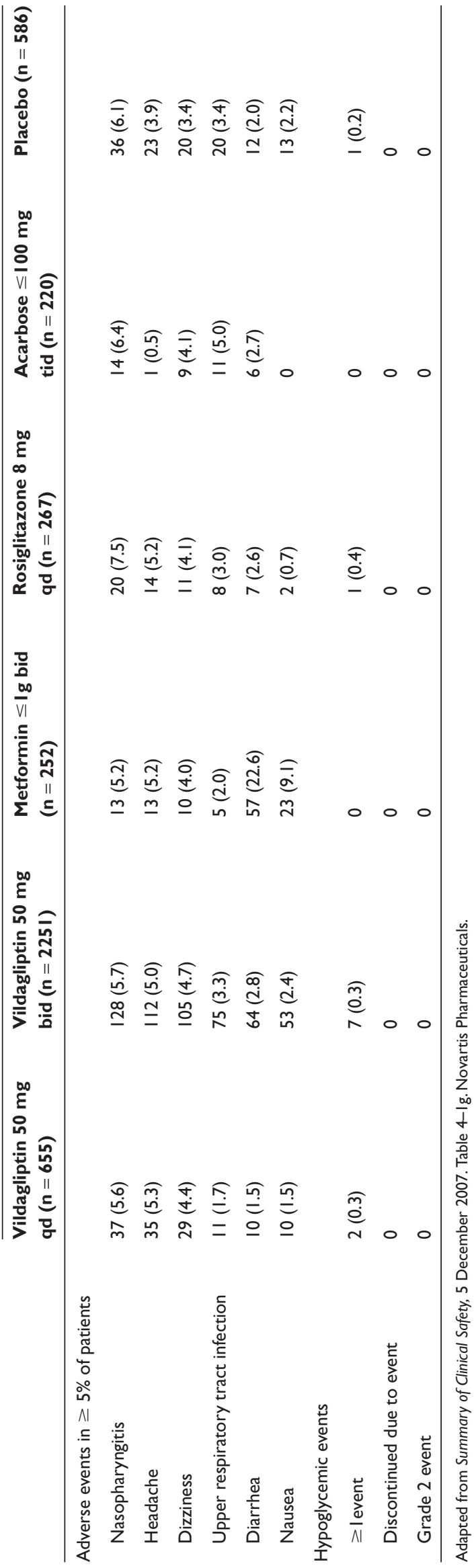




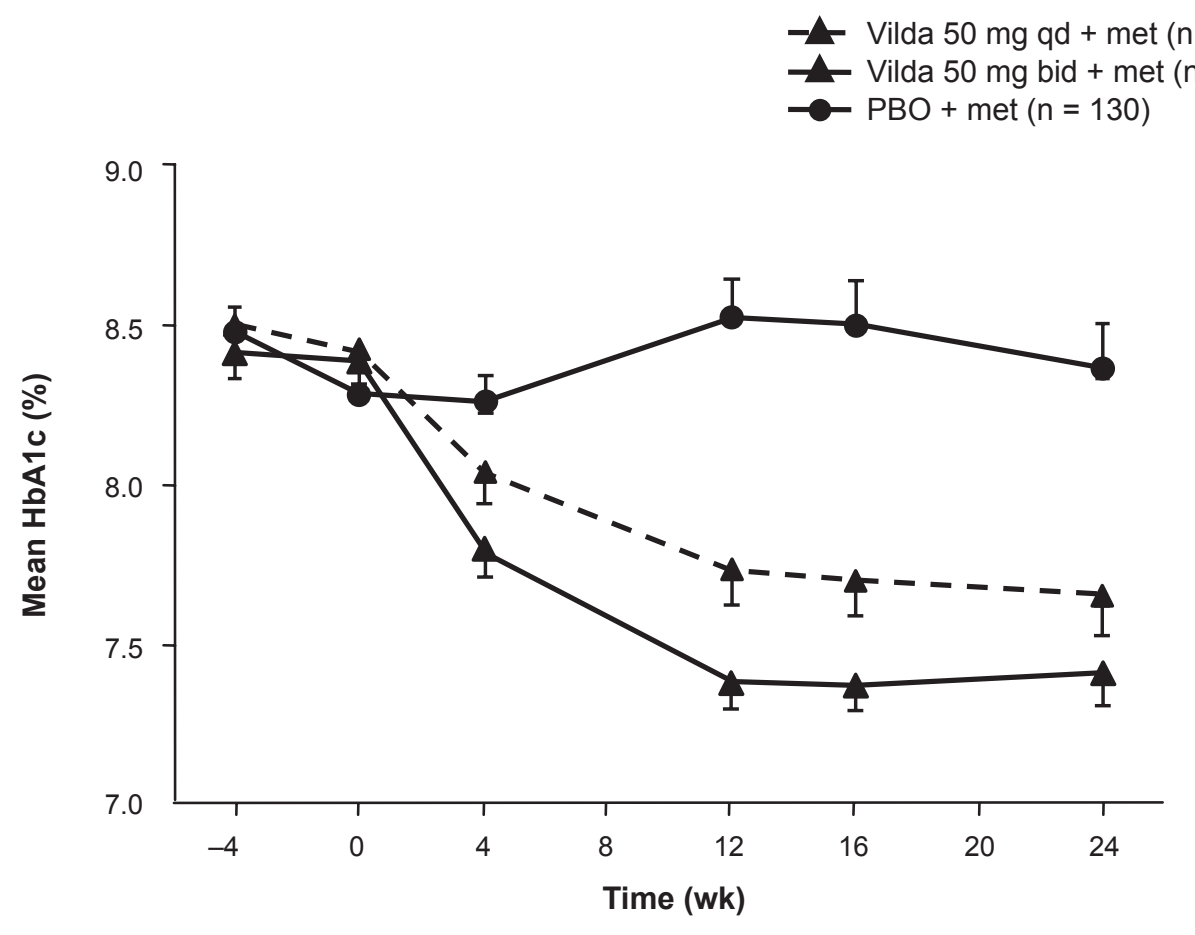

${ }^{*} p<0.001$ vs PBO; Mean \pm SE primary IT T population (intention-to-treat).

HbA1c, glycosylated hemoglobin; ITT, intention-to-treat; met, metformin; PBO, placebo; vilda, vildagliptin.

Figure I Mean HbAlc \pm SE in patients receiving vildagliptin qd or bid or placebo as an add-on to metformin therapy ( $\geq 1500 \mathrm{mg} / \mathrm{d})$. Reproduced with permission from Bosi $\mathrm{E}$, Camisasca RP, Collober C, et al 2007a. Effects of vildagliptin on glucose control over 24 weeks in patients with type 2 diabetes inadequately controlled with metformin. Diabetes Care, 30:890-5. Copyright $\odot 2007$ American Diabetes Association.

$\operatorname{bid}\left(\mathrm{n}=57 ;+7.3 \mathrm{pmol} / \mathrm{min} / \mathrm{m}^{2} / \mathrm{mM}\right)$ vs metformin/placebo $\left(\mathrm{n}=54 ;+1.6 \mathrm{pmol} / \mathrm{min} / \mathrm{m}^{2} / \mathrm{mM} ; \mathrm{p} \leq 0.001\right.$ for both comparisons); adjusted mean changes in 2-hour postprandial glucose were $-1.9,-2.3$, and $-0.1 \mathrm{mmol} / \mathrm{L}$, respectively $(\mathrm{p} \leq 0.001$ for both vs metformin/placebo) (Bosi et al 2007a) (data on file, Novartis).

There were no significant changes in body weight from baseline (mean $93-95 \mathrm{~kg}$ ) with vildagliptin qd $(-0.4 \mathrm{~kg})$ or bid $(+0.2 \mathrm{~kg})$ and a significant decrease with metformin/ placebo $(-1.0 \mathrm{~kg}, \mathrm{p}<0.001)$ (Bosi et al 2007). Among patients with baseline DPB $\geq 90 \mathrm{mmHg}$ and $\mathrm{SBP} \geq 140$ $\mathrm{mmHg}$ (vildagliptin $50 \mathrm{mg}$ bid, $\mathrm{n}=57$; metformin/placebo, $\mathrm{n}=59$ ), reductions in DBP were $-4.0 \mathrm{mmHg}$ with vildagliptin $50 \mathrm{mg}$ bid $(\mathrm{p}<0.05)$ and $-0.9 \mathrm{mmHg}$ with metformin/placebo $(p=N S)$ and reductions in SBP were -9.8 $(\mathrm{p}<0.05)$ and $-6.3(\mathrm{p}<0.05)$, respectively. Vildagliptin had a neutral effect on fasting lipids; changes for vildagliptin qd, vildagliptin bid, and metformin/placebo were, respectively, $+1.0 \%(\mathrm{p}=0.014 \mathrm{vs}$ metformin/placebo $),+4.8 \%$, and $+18.4 \%$ for triglycerides; $-1.6 \%,-1.8 \%$, and $+1.7 \%$ for total cholesterol $;+0.4 \%,+1.8 \%$, and $+0.7 \%$ for LDL cholesterol; and $-0.6 \%,+0.2 \%$, and $+2.0 \%$ for HDL cholesterol. Adverse events occurred with similar frequency in all treatment groups
(63.3\%-65.0\%), with GI adverse events occurring in 9.6\% of patients ( $p=0.022 \mathrm{vs}$ metformin/placebo) on vildagliptin qd, $14.8 \%$ of those on vildagliptin bid, and $18.2 \%$ of those on metformin/placebo. Mild hypoglycemia occurred in one patient in each group $(0.6 \%$ with vildagliptin qd, $0.5 \%$ with vildagliptin bid, and $0.6 \%$ with metformin/placebo).

\section{Add-on to metformin vs pioglitazone add-on}

In a noninferiority trial, 576 patients with inadequate glycemic control (HbA1c 7.5\%-11.0\%; mean 8.4\%) on stable metformin $\geq 1500 \mathrm{mg} / \mathrm{d}$ were randomized to vildagliptin $50 \mathrm{mg}$ bid $(\mathrm{n}=295)$ or pioglitazone $30 \mathrm{mg}$ qd $(n=281)$ plus continued metformin for 24 weeks; the metformin dose was titrated up to $\geq 2000 \mathrm{mg} / \mathrm{d}$ by study baseline, and the average study dose was approximately $2000 \mathrm{mg} / \mathrm{d}$ (Bolli et al 2008). Adjusted mean changes in HBA1c were $-0.9 \%$ with vildagliptin vs $-1.0 \%$ with pioglitazone, with vildagliptin meeting the noninferiority criterion (Figure 2). Among patients with baseline $\mathrm{HbA1c}>9.0 \%$ (vildagliptin, $\mathrm{n}=63$; pioglitazone, $\mathrm{n}=58$; baseline $\sim 9.7 \%$ ), $\mathrm{HbA} 1 \mathrm{c}$ was reduced by $1.5 \%$ in both groups. FPG (baseline mean $\sim 11.0 \mathrm{mmol} / \mathrm{L}$ ) was reduced by adjusted means of 


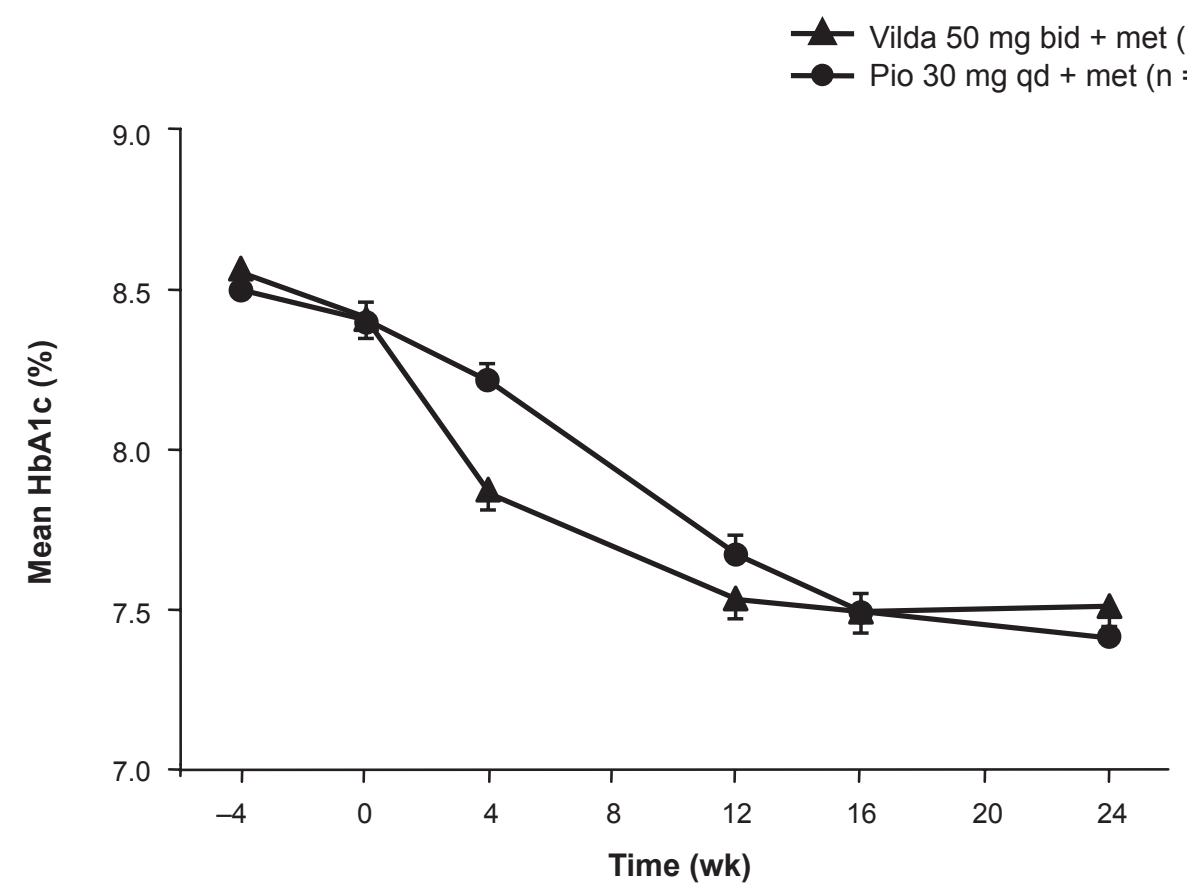

Mean \pm SE per protocol population

HbA1c, glycosylated hemoglobin; met, metformin; PBO, placebo; pio, pioglitazone; vilda, vildagliptin.

Figure 2 Mean HbA Ic \pm SE in patients receiving vildagliptin or pioglitazone as an add-on to ongoing metformin therapy ( $\geq 1500 \mathrm{mg} / \mathrm{d})$. Bolli $\mathrm{G}$, Dotta F, Rochotte $\mathrm{E}$, Cohen SE. 2008. Efficacy and tolerability of vildagliptin vs pioglitazone when added to metformin: a 24-week, randomized, double-blind study. Diabetes Obes Metab, I0:82-90. Copyright (c) Blackwell Publishing.

$1.4 \mathrm{mmol} / \mathrm{L}$ with vildagliptin and $2.1 \mathrm{mmol} / \mathrm{L}$ with pioglitazone, with vildagliptin not meeting the noninferiority criterion. The latter finding reflects differences in mechanism of action of the two agents: insulin-sensitizing thiazolidinediones have more of an effect during fasting, whereas vildagliptin exerts its glucose-dependent effect in the postprandial period. Change in body weight among all patients (baseline $\sim 91 \mathrm{~kg}$ ) was $+0.3 \mathrm{~kg}$ with vildagliptin vs $+1.9 \mathrm{~kg}$ with pioglitazone $(\mathrm{p}<0.001)$; the change among patients with baseline BMI $\geq 35 \mathrm{~kg} / \mathrm{m}^{2}$ (vildagliptin, $\mathrm{n}=73$; pioglitazone, $\mathrm{n}=70$, baseline $\sim 110 \mathrm{~kg}$ ) was $+0.1 \mathrm{~kg}$ with vildagliptin vs $+2.6 \mathrm{~kg}$ with pioglitazone $(\mathrm{p}<0.001)$. Adverse events occurred with similar frequency in the vildagliptin and pioglitazone groups (56.4\% and 60.0\%, respectively). Surprisingly, an unusually high frequency of peripheral edema was reported in vildagliptin patients $(8.8 \%$, vs $6.1 \%$ with pioglitazone); this finding may reflect the specific criteria used for identifying edema in the study and/or the much greater frequency of edema in vildagliptin patients receiving calcium channel blocker therapy vs no edema in pioglitazone patients receiving such concomitant treatment. In another study of initial combination therapy with pioglitazone and vildagliptin, which contained monotherapy arms, peripheral edema was reported in $9.3 \%$ of the pioglitazone monotherapy group, $5.2 \%$ of the vildagliptin monotherapy group, and $6.1 \%$ of the combination therapy group (Bolli et al 2007). Mild hypoglycemia occurred in one vildagliptin patient and in none of the pioglitazone patients.

\section{Combination with other antidiabetic drugs Add-on to $S U$ vs placebo}

A total of 515 patients with inadequate glycemic control on SU monotherapy (HbAlc 7.5\%-11.0\%; mean 8.5\%-8.6\%) were randomized to vildagliptin $50 \mathrm{mg} \mathrm{qd}(\mathrm{n}=170)$ or $50 \mathrm{mg}$ bid $(n=169)$ or placebo $(n=176)$ plus glimepiride $4 \mathrm{mg} \mathrm{qd}$ for 24 weeks (Garber 2008). Placebo-subtracted reductions in $\mathrm{HbA} 1 \mathrm{c}$ were $0.6 \%$ with vildagliptin qd and $0.7 \%$ with vildagliptin bid (both $\mathrm{p}<0.001$ ). Although both reductions were significant, there was no dose response observed with the higher vildagliptin dose; vildagliptin is approved for use in combination with an SU at $50 \mathrm{mg}$ qd. Changes in patients with baseline HbA1c $>9.0 \%$ (vildagliptin $\mathrm{qd}, \mathrm{n}=32$; glimepiride/placebo, $n=4$; baseline $9.8 \%$ ) were $-1.0 \%$ with vildagliptin $50 \mathrm{mg}$ qd and $0.0 \%$ with glimepiride/placebo; changes in patients aged $\geq 65$ years (vildagliptin $q d, n=41$; glimepiride/placebo, $\mathrm{n}=38$; baseline $8.5 \%$ ) were $-0.7 \%$ and $+0.1 \%$, respectively. Adverse events were similar in 
frequency with vildagliptin $50 \mathrm{mg}$ qd and with glimepiride/ placebo (67.1\% and $64.2 \%$, respectively). Hypoglycemia occurred in two patients $(1.2 \%)$ receiving vildagliptin $50 \mathrm{mg}$ qd and one patient $(0.6 \%)$ receiving glimepiride/placebo. Body weight decreased slightly with both treatments $(-0.1 \mathrm{~kg}$ and $-0.4 \mathrm{~kg}$ ).

\section{Add-on to pioglitazone vs placebo}

A total of 463 patients with inadequate glycemic control on thiazolidinedione treatment (HbA1c 7.5\%-11.0\%, mean $8.6 \%-8.7 \%$ ) were randomized to vildagliptin $50 \mathrm{mg} \mathrm{qd}$ $(\mathrm{n}=147)$ or $50 \mathrm{mg}$ bid $(\mathrm{n}=158)$ or to placebo $(\mathrm{n}=158)$ plus maximum-dose pioglitazone at $45 \mathrm{mg}$ qd for 24 weeks (Garber et al 2007). Changes in HbA1c were $-0.8 \%$ with vildagliptin qd and $-1.0 \%$ with vildagliptin bid, vs $-0.3 \%$ with pioglitazone/placebo ( $\mathrm{p} \leq 0.001$ for both comparisons). Adverse events were similar in frequency in all groups (48.7\%-55.5\%). Mild hypoglycemia occurred in none of the patients with vildagliptin $\mathrm{qd}$, in one patient $(0.6 \%)$ with vildagliptin bid, and in 3 patients $(1.9 \%)$ with pioglitazone/ placebo. Body weight increased by $1.4 \mathrm{~kg}$ with placebo/ pioglitazone and by an additional $0.1 \mathrm{~kg}$ with vildagliptin qd and an additional $1.3 \mathrm{~kg}$ with vildagliptin bid ( $\mathrm{p}=0.003 \mathrm{vs}$ placebo/pioglitazone). No consistent or dose-related changes in lipids were observed with the addition of vildagliptin to pioglitazone.

\section{Add-on to insulin vs placebo}

A total of 296 patients with inadequate glycemic control on insulin (HbA1c 7.5\%-11.0\%, baseline $\sim 8.4 \%$, mean duration of insulin use $\sim 6$ years) received vildagliptin $50 \mathrm{mg}$ bid $(n=144)$ or placebo $(n=152)$ plus ongoing insulin for 24 weeks; the mean daily insulin dose at baseline was 81.2-81.9 U, and dose adjustments were permitted during the study (Fonseca 2007). The change in insulin dose was $+1.2 \mathrm{U}$ in the vildagliptin group and $+4.1 \mathrm{U}$ in the insulin/placebo group. Changes in $\mathrm{HbA} 1 \mathrm{c}$ were $-0.5 \%$ with vildagliptin and $-0.2 \%$ with insulin/placebo $(\mathrm{p}=0.01)$; among patients aged $\geq 65$ years (vildagliptin, $n=42$; insulin/placebo, $n=41$; baseline $8.4 \%$ ), changes were $-0.7 \%$ with vildagliptin add-on and $-0.1 \%$ with insulin/placebo. Vildagliptin was associated with significant reductions in number of hypoglycemic episodes $(113$ vs $185, \mathrm{p}<0.001)$ and number of severe events ( 0 vs $6, p<0.05)$. The change in body weight was $+1.3 \mathrm{~kg}$ in vildagliptin/insulin patients and $+0.6 \mathrm{~kg}$ in insulin $/$ placebo patients.

In an extension of this trial, 96 patients on vildagliptin $50 \mathrm{mg}$ bid continued on treatment and 104 in the insulin/placebo group switched to vildagliptin $50 \mathrm{mg} \mathrm{qd}$ plus ongoing insulin for an additional 28 weeks (total 52 weeks) (Fonseca et al 2008). During the extension phase, the average insulin dose increased by approximately $2 \mathrm{U}$. At 52 weeks, the efficacy of vildagliptin $50 \mathrm{mg}$ bid in reducing $\mathrm{HbA} 1 \mathrm{c}$ was maintained $(-0.5 \%)$; in patients receiving vildagliptin $50 \mathrm{mg}$ qd, the change between week 24 and week 52 was $-0.4 \%$. In patients aged $\geq 65$ years receiving $50 \mathrm{mg}$ bid, the change in HbA1c at 52 weeks was $-0.9 \%$, compared with $-0.24 \%$ in younger patients, indicating that overall efficacy primarily reflected the effect in older patients. There was no significant change in body weight with continued $50 \mathrm{mg}$ bid treatment $(+0.3 \mathrm{~kg}$ during the extension; $+1.8 \mathrm{~kg}$ over 52 weeks) or during the extension in patients switched to $50 \mathrm{mg}$ qd $(+0.5 \mathrm{~kg})$. The rate of hypoglycemic events per patient-year was 1.80 in the $50 \mathrm{mg}$ bid group and 1.78 in the $50 \mathrm{mg}$ qd group, compared with 2.66 in the insulin/placebo group during the core study; in the elderly patients, event rates were 2.1 and 2.3 in the vildagliptin groups, compared with 3.3 in insulin/placebo patients during the core study.

\section{Initial combination with pioglitazone}

A total of 607 treatment-naïve patients (HbA1c 7.5\%-11.0\%, mean $\sim 8.7 \%$ ) were randomized to vildagliptin $100 \mathrm{mg}$ qd $(\mathrm{n}=154)$, pioglitazone $30 \mathrm{mg}$ qd $(\mathrm{n}=161)$, vildagliptin $50 \mathrm{mg}$ qd plus pioglitazone $15 \mathrm{mg}$ qd, or vildagliptin $100 \mathrm{mg}$ qd plus pioglitazone $30 \mathrm{mg}$ qd for 24 weeks (Rosenstock et al 2007b). Changes in HbA1c were $-1.1 \%$ with vildagliptin alone, $-1.4 \%$ with pioglitazone alone, $-1.7 \%$ with the $50 \mathrm{mg} / 15 \mathrm{mg}$ combination ( $\mathrm{p}<0.05$ vs pioglitazone alone), and $-1.9 \%$ with the $100 \mathrm{mg} / 30 \mathrm{mg}$ combination $(\mathrm{p}<0.001$ vs pioglitazone alone). The target $\mathrm{HbA} 1 \mathrm{c}$ level of $<7.0 \%$ was achieved in $43 \%, 43 \%, 54 \%$, and $65 \%$ of patients, respectively ( $\mathrm{p}<0.001$ for the $100 \mathrm{mg} / 30 \mathrm{mg}$ combination vs both monotherapy groups). Among patients with baseline $\mathrm{HbA} 1 \mathrm{c}$ $>9.0 \%$ (average $\sim 10.0 \%$ ), reductions were $1.5 \%$ with vildagliptin alone $(n=46), 1.8 \%$ with pioglitazone alone $(n=54)$, $2.3 \%$ with the $50 \mathrm{mg} / 15 \mathrm{mg}$ combination $(\mathrm{n}=49)$, and $2.8 \%$ with the $100 \mathrm{mg} / 30 \mathrm{mg}$ combination $(\mathrm{n}=54)(\mathrm{p}<0.001$ for the higher-dose combination vs pioglitazone alone). Among patients aged $\geq 65$ years, reductions were $1.3 \%$ with vildagliptin alone $(n=17), 1.2 \%$ with pioglitazone alone $(n=19)$, $1.7 \%$ with the $50 \mathrm{mg} / 15 \mathrm{mg}$ combination $(\mathrm{n}=15)$, and $2.3 \%$ with the $100 \mathrm{mg} / 30 \mathrm{mg}$ combination $(\mathrm{n}=21)(\mathrm{p}<0.001$ for the higher-dose combination vs pioglitazone alone). Changes in body weight (mean $80-82 \mathrm{~kg}$ ) were $+0.2 \mathrm{~kg}$ with vildagliptin monotherapy, $+1.5 \mathrm{~kg}$ with pioglitazone monotherapy, $+1.4 \mathrm{~kg}$ with the $50 \mathrm{mg} / 15 \mathrm{mg}$ combination, and $+2.1 \mathrm{~kg}$ with 
the $100 \mathrm{mg} / 30 \mathrm{mg}$ combination. Adverse event rates were comparable in all groups $(45.8 \%-51.6 \%)$. Rates of edema were $5.2 \%$ with vildagliptin alone, $9.3 \%$ with pioglitazone alone, $3.5 \%$ with the $50 \mathrm{mg} / 15 \mathrm{mg}$ combination, and $6.1 \%$ with the $100 \mathrm{mg} / 30 \mathrm{mg}$ combination. Hypoglycemia occurred in one patient $(0.7 \%)$ receiving vildagliptin monotherapy and in one $(0.7 \%)$ receiving the $100 \mathrm{mg} / 30 \mathrm{mg}$ combination.

\section{Summary of pooled combination study adverse events}

Pooled adverse event data from vildagliptin combination studies, shown in Table 2, indicate good tolerability with vildagliptin in combination with other antidiabetic agents.

\section{Discussion and conclusion}

The availability of a new class of agents in our therapeutic toolkit for the treatment of hyperglycemia in T2DM is of great importance to reduce the burden of diabetes. In the new group of inhibitors of DPP-4, vildagliptin proves to be a very efficacious drug for improving glycemic control in a wide range of T2DM patients, ranging from the IGT population to patients with advanced disease on insulin. Its potential for lowering $\mathrm{HbA} 1 \mathrm{c}$ is in the range of that of thiazolidinediones and acarbose in monotherapy, and sustained efficacy for up to 2 years has been demonstrated. The effect of improving postprandial glycemia provides a good alternative for the up till now limited therapeutic options of affecting postprandial glycemia excursion. In addition, also fasting glycemia is clearly affected by vildagliptin.
Compared to the other gliptins, vildagliptin distinguishes itself by behaving like a surrogate substrate, being altered itself by the enzyme DPP-4 (Ahrén and Foley 2008). No head-to-head comparison clinical trials between the different gliptins are available at present, so that only indirect comparisons can be made. HbA1c lowering effects seem to be comparable over the spectrum of gliptins, whereas some studies indicate a greater reduction of fasting glycemia for sitagliptin (Amori et al 2007).

The most interesting combination in which to use vildagliptin is with metformin, for two different reasons. First, from a pathogenic perspective, combining an agent primarily targeting insulin resistance, like metformin, with an agent primarily targeting the $\beta$-cell, like vildagliptin, is a logical approach. In addition, the choice of vildagliptin gives the added value of also targeting the $\alpha$-cell dysfunction that is clearly present in T2DM patients, with insufficient suppression of glucagon secretion leading to postprandial hyperglycemia. Second, more than additive effects have been observed with this combination. Indeed, metformin has been found to increase GLP-1 levels, presumably through increasing GLP-1 synthesis rather than DPP-4 inhibition (Hinke et al 2002; Yasuda et al 2002; Migoya et al 2007). One study found that vildagliptin administration in treatment-naïve patients $(n=5)$ resulted in a prandial active GLP-1 level of approximately $10 \mathrm{pmol} / \mathrm{L}$ and that the addition of vildagliptin in metformintreated patients $(n=12)$ resulted in a level more than twice as high ( $\mathrm{p}<0.05)$ (Dunning et al 2006). Based on these reasons, the combination of vildagliptin with metformin will be a

Table 2 Incidence of adverse events ( $\geq 5 \%$ ) in vildagliptin combination trials (pooled data at 24 weeks)

\begin{tabular}{|c|c|c|c|c|}
\hline & \multicolumn{4}{|l|}{ No (\%) } \\
\hline & $\begin{array}{l}\text { Vildagliptin } \\
50 \mathrm{mg} \text { qd }(\mathrm{n}=693)\end{array}$ & $\begin{array}{l}\text { Vildagliptin } \\
50 \text { mg bid }(n=2343)\end{array}$ & $\begin{array}{l}\text { Total placebo } \\
(n=7 \mid 8)\end{array}$ & $\begin{array}{l}\text { Total comparators } \\
(\mathrm{n}=2387)\end{array}$ \\
\hline Any & 411 (59.3) & I 466 (62.6) & $468(65.2)$ & $1611(67.5)$ \\
\hline \multicolumn{5}{|l|}{$\begin{array}{l}\text { Adverse events } \\
\text { in } \geq 5 \% \text { of patients }\end{array}$} \\
\hline Nasopharyngitis & $44(6.3)$ & $126(5.4)$ & $4 \mid(5.7)$ & $134(5.6)$ \\
\hline Dizziness & $33(4.8)$ & $125(5.3)$ & $43(6.0)$ & 207 (8.7) \\
\hline Headache & $34(4.9)$ & $125(5.3)$ & $21(2.9)$ & II 4 (4.8) \\
\hline Influenza & $18(2.6)$ & $86(3.7)$ & $40(5.6)$ & $83(3.5)$ \\
\hline Asthenia & $22(3.2)$ & $85(3.6)$ & $28(3.9)$ & $146(6.1)$ \\
\hline Tremor & $23(3.3)$ & $85(3.6)$ & $47(6.5)$ & $296(12.4)$ \\
\hline $\begin{array}{l}\text { Upper respiratory } \\
\text { tract infection }\end{array}$ & $32(4.6)$ & $75(3.2)$ & $4 \mid(5.7)$ & 77 (3.2) \\
\hline Hyperhidrosis & $17(2.5)$ & $73(3.1)$ & $4 \mid(5.7)$ & $247(10.3)$ \\
\hline
\end{tabular}

ancludes both active comparators (including insulin) and placebo.

Adapted from Summary of Clinical Safety, 5 December 2007. Table 4-Ic. Novartis Pharmaceuticals, data on file. 
treatment of choice in T2DM patients, but ingesting multiple pills per day severely hampers patient compliance, especially in this already polymedicated population. Fixed-dose combinations may improve treatment compliance. Studies have shown significantly greater adherence rates (Melikian et al 2002; Blonde et al 2003) and improved glycemic control (Blonde et al 2003) with a fixed-dose combination of metformin/glyburide than with a free-drug component combination of the two. Investigation of a fixed-dose combination of vildagliptin $50 \mathrm{mg}$ and metformin $1000 \mathrm{mg}$ showed equivalent plasma concentrations of both vildagliptin and metformin with the fixed-dose combination compared with the free component combination (He et al 2008c). The fixeddose vildagliptin/metformin combination in formulations of vildagliptin $50 \mathrm{mg} / \mathrm{metformin} 850 \mathrm{mg}$ and vildagliptin $50 \mathrm{mg} / \mathrm{metformin} 1000 \mathrm{mg}$ was recently approved in the European Union and may thus be a treatment of choice, even early on in the therapy of T2DM patients.

In our efforts to control glucose levels in T2DM patients, efficacy of the treatment in terms of glucose-lowering potential is, however, only one aspect of therapy. Side effects, such as hypoglycemia and weight gain, or simply overall tolerance of the treatment will determine usability. Vildagliptin presents a very desirable profile here, with monotherapy studies showing low risk for hypoglycemia, no weight gain, and an incidence of edema, gastrointestinal symptoms, and other adverse events similar to that seen with placebo.

When combining the data on efficacy and on safety, it is clear that most T2DM patients with sufficient beta-cell reserve will benefit from therapy with vildagliptin. Especially patients where hypoglycemia needs to be avoided at all cost, like elderly patients or patients with active professional lives, or where weight gain is a major concern, will benefit from this treatment (Mathieu and Bollaerts 2007). The drug profile makes it a first line choice when thinking of a tool to increase beta-cell insulin secretion.

Vildagliptin is currently approved in the European Union (26 September 2007, European Medicines Agency [EMEA]) for use in combination with metformin and thiazolidinediones at $50 \mathrm{mg}$ bid and with SU at $50 \mathrm{mg}$ qd, with fixed-dose combinations with metformin $(50 \mathrm{mg} / 850 \mathrm{mg}$ and $50 \mathrm{mg} / 1000 \mathrm{mg}$ ) also available for use (14 November 2007, EMEA) (Galvus EU PI; Eucreas EU PI). Based on observations using higher doses than the ones proposed for clinical use, a caution for liver dysfunction was built in to the label. Vildagliptin should not be used in patients with hepatic impairment. Rare cases of hepatic dysfunction have been reported; therefore, liver function tests should be performed prior to initiation of treatment, at 3-month intervals during the first year, and periodically thereafter.

Whereas vildagliptin may be used throughout the whole spectrum of T2DM patients, an interesting observation was made in patients where vildagliptin was combined with insulin. In these patients, an insulin sparing effect was seen, but more interestingly, less hypoglycemia was observed. No direct explanation is available, but further exploration of this phenomenon is warranted because of great clinical importance.

Finally, there remains the promise of beta-cell protection in the long term. At present, only theoretical considerations and animal data are available, suggesting this will indeed be the case for vildagliptin. In clinical trials, long-term data are scarce, with 2-year data available only recently (Scherbaum et al 2008b) to suggest that in the studied subgroup a change in residual beta-cell function was indeed present in patients treated with vildagliptin for 2 years.

\section{Acknowledgments}

C Mathieu gratefully acknowledges the editorial assistance provided by BioScience Communications of New York, NY, in the production of this manuscript.

\section{Disclosures}

$\mathrm{C}$ Mathieu has received consultancy fees and research support from MSD, Eli Lilly, Novo Nordisk, and Novartis. E Degrande has no conflicts to disclose.

\section{References}

Ahrén B, Foley JE. 2008. The islet enhancer vildagliptin: mechanisms of improved glucose metabolism. Int J Clin Pract Suppl, 159:8-14.

Ahrén B, Landin-Olsson M, Jansson P, et al. 2004. Inhibition of dipeptidyl peptidase-4 reduces glycemia, sustains insulin levels and reduces glucagon levels in type 2 diabetes. J Clin Endocrinol Metab, 89:2078-84.

Ahrén B, Pacini G, Foley JE, Schweizer A. 2005. Improved meal-related beta-cell function and insulin sensitivity by the dipeptidyl peptidase-IV inhibitor vildagliptin in metformin-treated patients with type 2 diabetes over 1 year. Diabetes Care, 28:1936-40.

Amori R, Lau J, Pittas A. 2007. Efficacy and safety of incretin therapy in type 2 diabetes: systematic review and meta-analysis. JAMA, 298:194-206.

Azuma K, Rádiková Z, Mancino J, et al. 2008. Measurements of islet function and glucose metabolism with the DPP-4 inhibitor vildagliptin in patients with type 2 diabetes. J Clin Endocrinol Metab, 93:459-64.

Baggio LL, Drucker DJ. 2006. Therapeutic approaches to preserve islet cell mass in type 2 diabetes. Annu Rev Med, 57:265-81.

Balas B, Baig MR, Watson C, et al. 2007. The dipeptidyl peptidase IV inhibitor vildagliptin suppresses endogenous glucose production and enhances islet function after single-dose administration in type 2 diabetic patients. J Clin Endocrinol Metab, 92:1249-55.

Blonde L, Wogen J, Kreilick C, Seymour AA. 2003. Greater reductions in A1C in type 2 diabetic patients new to therapy with glyburide/metformin tablets as compared to glyburide co-administered with metformin. Diabetes Obes Metab, 5:424-31. 
Bolli G, Dotta F, Rochotte E, Cohen SE. 2008. Efficacy and tolerability of vildagliptin vs pioglitazone when added to metformin: a 24-week, randomized, double-blind study. Diabetes Obes Metab, 10:82-90.

Bosi E, Byiers SR, Cohen SE. 2007b. Vildagliptin significantly decreases blood pressure (BP) in hypertensive patients (pts) with type 2 diabetes (T2DM) compared with metformin [abstract]. Diabetes, 56(suppl 1): A139. Abstract 521-P.

Bosi E, Camisasca RP, Collober C, et al. 2007a. Effects of vildagliptin on glucose control over 24 weeks in patients with type 2 diabetes inadequately controlled with metformin. Diabetes Care, 30:890-5.

Burkey BF, Russell M, Wang K, et al. 2006. Vildagliptin displays slow tight-binding to dipeptidyl peptidase (DPP)-4, but not DPP-8 or DPP-9. Diabetologia, 49(suppl 1):477. Abstract 0788

D'Alessio D, Watson CE, He Y, et al. 2006. Restoration of an acute insulin response to glucose (AIRg) in drug naïve patients with type 2 diabetes (T2DM) by 3-month treatment with vildagliptin. Diabetes, 55(suppl 1): A108. Abstract 454-P.

Deacon CF, Carr RD, Holst JJ. 2008. DPP-4 inhibitor therapy: new directions in the treatment of type 2 diabetes. Front Biosci, 13:1780-94.

Deacon CF. 2004. Therapeutic strategies based on glucagon-like peptide-1. Diabetes, 53:2181-9.

Dejager S, Razac S, Foley JE, Schweizer A. 2007. Vildagliptin in drugnaïve patients with type 2 diabetes: a 24 -week, double-blind, randomized, placebo-controlled, multiple-dose study. Horm Metab Res, 39:218-23.

Drucker DJ. 2006. The biology of incretin hormones. Cell Metab, 3:153-65.

Dunning BE, Ligueros-Saylan M, D’Alessio DA, et al. 2006. Differential effects of DPP-4 inhibition on incretin hormone levels in drug-naïve and metformin-treated patients with type 2 diabetes. Diabetologia, 49(suppl 1):110-1. Abstract 0174.

Eucreas [package insert]. 2008. West Sussex, UK: Novartis Europharm.

Fonseca V, Baron M, Shao Q, Dejager S. 2008. Sustained efficacy and reduced hypoglycemia during one year of treatment with vildagliptin added to insulin in patients with type 2 diabetes mellitus. Horm Metab Res, 40:427-30.

Fonseca V, Schweizer A, Albrecht D, et al. 2007. Addition of vildagliptin to insulin improves glycaemic control in type 2 diabetes. Diabetologia, 50:1148-55.

Galvus [package insert]. 2008. West Sussex, UK: Novartis Europharm.

Garber AJ, Foley JE, Banerji MA, et al. 2008. Effects of vildagliptin on glucose control in patients with type 2 diabetes inadequately controlled with a sulphonylurea. Diabetes Obes Metab, Feb 18 [Epub ahead of print].

Garber AJ, Schweizer A, Baron MA, et al. 2007. Vildagliptin in combination with pioglitazone improves glycemic control in patients with type 2 diabetes failing thiazolidinedione monotherapy: a randomized, placebocontrolled study. Diabetes Obes Metab, 9:166-74.

He YL, Flannery B, Campestrini J, et al. 2008d. Effect of food on the pharmacokinetics of a vildagliptin/metformin $(50 / 1000 \mathrm{mg})$ fixeddose combination tablet in healthy volunteers. Curr Med Res Opin, 24:1703-9.

He YL, Ligueros-Saylan M, Sunkara G, et al. 2008b. Vildagliptin, a novel dipeptidyl peptidase IV inhibitor, has no pharmacokinetic interactions with the antihypertensive agents amlodipine, valsartan, and ramipril in healthy subjects. J Clin Pharmacol, 48:85-95.

He YL, Paladini S, Sabia H, et al. 2008c. Bioequivalence of vildagliptin/ metformin fixed-dose combination tablets and a free combination of vildagliptin and metformin in healthy subjects. Int J Clin Pharmacol Ther, 46:259-67.

He YL, Sabo R, Campestrini J, et al. 2007e. The influence of hepatic impairment on the pharmacokinetics of the dipeptidyl peptidase IV (DPP-4) inhibitor vildagliptin. Eur J Clin Pharmacol, 63:677-86.

He YL, Sabo R, Campestrini J, et al. 2008a. The effect of age, gender, and body mass index on the pharmacokinetics and pharmacodynamics of vildagliptin in healthy volunteers. Br J Clin Pharmacol, 65:338-46.
He YL, Sabo R, Riviere GJ, et al. 2007d. Effect of the novel oral dipeptidyl peptidase IV inhibitor vildagliptin on the pharmacokinetics and pharmacodynamics of warfarin in healthy subjects. Curr Med Res Opin, 23:1131-8.

He YL, Sabo R, Sunkara G, et al. 2007f. Evaluation of pharmacokinetic interactions between vildagliptin and digoxin in healthy volunteers. J Clin Pharmacol, 47:998-1004.

He YL, Sadler BM, Sabo R, et al. 2007b. The absolute oral bioavailability and population-based pharmacokinetic modelling of a novel dipeptidylpeptidase-IV inhibitor, vildagliptin, in healthy volunteers. Clin Pharmacokinet, 46:787-802.

He YL, Serra D, Wang Y, et al. 2007c. Pharmacokinetics and pharmacodynamics of vildagliptin in patients with type 2 diabetes mellitus. Clin Pharmacokinet, 46:577-88.

He YL, Wang Y, Bullock J, et al. 2007a. Pharmacodynamics of vildagliptin in patients with type 2 diabetes during OGTT. J Clin Pharmacol, 47:633-41.

Hinke SA, Kühn-Wache K, Hoffman T, et al. 2002. Metformin effects on dipeptidylpeptidase IV degradation of glucagon-like peptide-1. Biochem Biophys Res Commun, 291:1302-8.

Kahn SE, Haffner SM, Heise MA, et al. 2006. Glycemic durability of rosiglitazone, metformin, or glyburide monotherapy. $N$ Engl $J$ Med, 355: $2427-43$

Mari A, Sallas WM, He YL, et al. 2005. Vildagliptin, a dipeptidyl peptidase-IV inhibitor, improves model-assessed beta-cell function in patients with type 2 diabetes. $J$ Clin Endocrinol Metab, 90:4888-94.

Mari A, Scherbaum WA, Nilsson PM, et al. 2008. Characterization of the influence of vildagliptin on model-assessed $\beta$-cell function in patients with type 2 diabetes and mild hyperglycemia. J Clin Endocrinol Metab, 93:103-9.

Mathieu C, Bollaerts K. 2007 Antihyperglycaemic therapy in elderly patients with type 2 diabetes: potential role of incretin mimetics and DPP-4 inhibitors. Int J Clin Pract Suppl, 154:29-37.

Matikainen N, Manttari S, Schweizer A, et al. 2006. Vildagliptin therapy reduces postprandial intestinal triglyceride-rich lipoprotein particles in patients with type 2 diabetes. Diabetologia, 49:2049-57.

Melikian C, White TJ, Vanderplas A, et al. 2002. Adherence to oral antidiabetic therapy in a managed care organization: a comparison of monotherapy, combination therapy, and fixed-dose combination therapy. Clin Ther, 24:460-7.

Migoya E, Miller J, Larson P, et al. 2007. Sitagliptin, a selective DPP-4 inhibitor, and metformin have complementary effects to increase active GLP-1 concentrations. Presented at the 43rd Annual Meeting of the European Association for the Study of Diabetes (EASD), Amsterdam, Netherlands. Abstract 0111.

Nathan DM, Buse JB, Davidson MB, et al. 2006. Management of hyperglycemia in type 2 diabetes: a consensus algorithm for the initiation and adjustment of therapy: a consensus statement from the American Diabetes Association and the European Association for the Study of Diabetes. Diabetes Care, 29:1963-72.

Pan C, Yang W, Barona JP, et al. 2008. Comparison of vildagliptin and acarbose monotherapy in patients with type 2 diabetes: a 24-week, double-blind, randomized trial. Diabet Med, 25:435-41.

Pi-Sunyer FX, Schweizer A, Mills D, Dejager S. 2007. Efficacy and tolerability of vildagliptin monotherapy in drug-naïve patients with type 2 diabetes. Diabetes Res Clin Pract, 76:132-8.

Rosenstock J, Baron MA, Camisasca R-P, et al. 2007b. Efficacy and tolerability of initial combination therapy with vildagliptin and pioglitazone compared with component monotherapy in patients with type 2 diabetes. Diabetes Obes Metab, 9:175-85.

Rosenstock J, Baron MA, Dejager S, et al. 2007a. Comparison of vildagliptin and rosiglitazone monotherapy in patients with type 2 diabetes. Diabetes Care, 30:217-23.

Rosenstock J, Foley JE, Rendell M, et al. 2008. Effects of the dipeptidyl peptidase inhibitor vildagliptin on incretin hormones, islet function, and postprandial glycemia in subjects with impaired glucose tolerance. Diabetes Care, 31:30-5. 
Saydah SH, Fradkin J, Cowie CC. 2004. Poor control of risk factors for vascular disease among adults with previously diagnosed diabetes. JAMA, 291:335-42.

Scherbaum WA, Schweizer A, Mari A, et al. 2008a. Efficacy and tolerability of vildagliptin in drug-naïve patients with type 2 diabetes and mild hyperglycaemia. Diabetes Obes Metab, 10:675-82.

Scherbaum WA, Schweizer A, Mari A, et al. 2008b. Evidence that vildagliptin attenuates deterioration of glycaemic control during 2-year treatment of patients with type 2 diabetes and mild hyperglycaemia. Diabetes Obes Metab, Mar 18 [Epub ahead of print].

Schweizer A, Couturier A, Foley JE, Dejager S. 2007. Comparison between vildagliptin and metformin to sustain reductions in $\mathrm{HbA} 1 \mathrm{c}$ over one year in drug-naive patients with type 2 diabetes. Diabet Med, 24:955-61.

Sunkara G, Sabo R, Wang Y, et al. 2007. Dose proportionality and the effect of food on vildagliptin, a novel dipeptidyl peptidase IV inhibitor, in healthy volunteers. J Clin Pharmacol, 47:1152-8.
UK Prospective Diabetes Study Group. 1998. Effect of intensive blood-glucose control with metformin on complications in overweight patients with type 2 diabetes (UKPDS 34). UK Prospective Diabetes Study (UKPDS) Group. Lancet, 352:854-65.

Utzschneider KM, Tong J, Montgomery B, et al. 2008. The dipeptidyl peptidase-4 inhibitor vildagliptin improves $\beta$-cell function and insulin sensitivity in subjects with impaired fasting glucose. Diabetes Care, 31:108-13.

Vella A, Bock G, Giesler PD, et al. 2007. Effects of dipeptidyl peptidase 4 inhibition on gastrointestinal function, meal appearance and glucose metabolism in type 2 diabetes. Diabetes, 56:1475-80.

Vilsbøll T, Holst JJ. 2004. Incretins, insulin secretion and type 2 diabetes mellitus. Diabetologia, 47:357-66.

Yasuda N, Inoue T, Nakagura T, et al. 2002. Enhanced secretion of glucagon-like peptide 1 by biguanide compounds. Biochem Biophys Res Commun, 298:779-84. 